\title{
The Potential of Biotechnology Investments in Selected Eastern European Countries: Lost Chances
}

\section{Patrik Vida}

Faculty for Commercial and Business Sciences, Celje, Slovenia

\begin{abstract}
Background: Biotechnology is rapidly developing on a global scale. However, some evidence indicates that Eastern European (EE) countries are not fulfilling their potential in this field. Objectives: This paper aims to examine whether selected EE countries are able to develop a strong biotechnology industry. Potential investment approaches and the existing but not used or neglected infrastructures in EE countries were also examined. Methods/approach: In order to determine biotechnological activities in EE countries, indicators such as intellectual property protection, venture capital availability, published scientific publications as well as other indicators were analyzed. These indicators were compiled and compared between EE countries and regions with a rich and diverse biotechnological business sector. Results: The results suggest an underdeveloped biotechnology business sector in EE countries, with talented but unexploited scientists and unutilized infrastructure. The systematic drawbacks of EE countries lead to a hostile investment environment. Conclusions: The findings make a significant contribution to understanding how the biotechnology industry in EE countries is structured and how investments can be rationally placed. EE countries need to adapt their venture capital market for biotechnology ventures. Several changes in regulations could have a large impact on biotechnology investments.
\end{abstract}

Keywords: biotechnology; investment; research and development; transition countries; Eastern Europe

JEL classification: $\mathrm{O} 31$

Paper type: Research article

Received: May 07, 2015

Accepted: Sep 13, 2015

Citation: Vida, P. (2016), "The Potential of Biotechnology Investments in Selected Eastern European Countries: Lost Chances", Business Systems Research, Vol. 7, No. 1, pp. 16-34.

DOI: 10.1515/bsrj-2016-0002

\section{Introduction}

The economy can be described as a sequence of transformations in technology and policy trough time (Essendorfer et al., 2015). During the transformation old technologies and procedures are being replaced by newer and more efficient ones. 
These transformations are creating waves of expanding and contracting gross domestic product of an economy. The benefits of an expanding economy are not shared equally (Kogan et al., 2015). To obtain the benefits of an expanding economy, accessibility of new and efficient technologies are crucial. Among the various new technologies, this study focuses on biotechnology. The aim of this study is to compare a set of regions, with a well-developed biotechnology business sector, with a group of selected Eastern European countries.

The impact of products from biotechnological companies on different aspects of the society is surprisingly large (Kishore \& Shewmaker, 1999). This impact on society has motivated researchers to investigate how to launch, finance and manage biotechnological companies. Typically, biotechnological companies strongly cluster (geographically) with universities and other biotechnological companies. This is a specialty of biotechnological in a surrounding of globalization of businesses and scientific research (Boschma et al., 2014).

Among the dedicated biotechnological companies we will focus on companies whose main area of activity is health care or medicine. We have selected these particular industries, since they are the most challenging part of the biotechnological sector, and are also highly capital intensive (Junkunc, 2007).

In our paper we focus on following selected Eastern European (EE) countries: Bulgaria, Czech Republic, Estonia, Hungary, Latvia, Lithuania, Poland, Romania, Slovakia and Slovenia. Above motioned ten countries share history of transition from centrally planned economy to market economy. In addition, and more recently, these countries became members of European Union (EU). This paper investigates the biotechnological landscape in the EE countries. Moreover, the paper is reviewing the use of the existing scientific and business infrastructure.

A goal of the paper is also to compare the development of biotechnology in $\mathrm{EE}$ countries with more developed regions and countries. We have selected following three regions with a well-developed biotechnology business sector: the Boston area, Switzerland and Singapore. We have selected these regions in order to cover diverse regions on different continents with a wide range of cultural and historical background. The approaches to the biotechnological business sector in these three regions are very different. Each of these three success stories is unique, but they also have some common themes, which will be investigated.

The paper is divided in seven sections. The first section serves as an introduction; the second part gives a definition of the term biotechnology and an historic overview of its development. The third section shows three internationally successful biotechnology regions. The following three sections are focusing on the local biotechnological surroundings in the EE countries. The fourth section focuses on the current situation of biotechnology investments in the selected EE countries; the fifth section describes the sources of low level biotechnology investments and the sixth looks for the potential of growth. The seventh and last section summarizes the ideas of this paper with its concluding thoughts.

\section{Origins and development of biotechnology}

The current definition of biotechnology used by the OECD reads as following: "The application of science and technology to living organisms, as well as parts, products and models thereof, to alter living or non-living materials for the production of knowledge, goods and services" (OECD, 2014).

This section will present a short overview of the terms used in the above definition and explain the basic concepts behind the definition. The term biotechnology was first described by Károly (Karl) Ereky in 1919 (Ereky, 1919). He described it as the 
combined use of biology and technology for turning raw materials into useful products. Ereky envisioned a science based biotechnology, which could hold the key to solving social inequities, like famine, energy shortage or health care (Fári \& Kralovánszky, 2006). According to the OECD definition, humankind has used the rudimentary form of biotechnology for millennia in agriculture, food products or medicine. Such examples are ancient brewers and bakers using yeast cultures to make beer and bread (Hulse, 2004).

In this paper the term biotechnology will be used in a more strict modern sense. Modern biotechnology is using genetic engendering tools to manipulate cell and DNA. Cells are the structural and functional basic biological units of all known living organisms. DNA is a long and coiled molecule in the nucleus of the cell, which holds the hereditary information. DNA is common to all living things as well as for certain viruses. It bears all the necessary instructions for the construction and operation of a life-form. The information is stored as the sequence of different nucleotides; nucleotides are the building blocks of the DNA molecule. The sequence of the different DNA building blocks - the nucleotides, defines the biological properties of the DNA molecule. All known organisms have chemically the same four nucleotides, but the DNA sequence of every individual differs. The hereditary information unit is classically viewed as gene (Pearson, 2006). Genes are sections of the DNA with a specific nucleotide sequence (Gerstein et al., 2007). Genes can hold information for proteins; therefore the gene sequence controls the properties of a protein. Proteins perform most of the structural and functional tasks of a living biological cell. The most frequent groups of proteins are: (1) enzymes, can chemically modify other compounds by accelerating chemical reactions; (2) signalling proteins, they rely messages for example from the outside of the cell to the inside of the cell; (3) immune system proteins, protect the organism against disease and other outside threats; and (4) structural proteins, which are responsible for the structural integrity of an organism. From this short list, the importance of properly working proteins should be clear. A malfunctioning or missing key protein can lead to malfunction of the affected cell and ultimately to disease (Gregersen et al., 2006). Biotechnology tries to apply the knowledge gained from the inner workings of a cell to make useful products, improve industrial chemical processes and make better medicine.

The work flow of a biotechnological project can be outlined in brief as follows: (a) identifying the target gene, which produces the gene product of interest; (b) identify and cut the gene fragment from a DNA sequence; (c) place the gene fragment into a vector, this a engineered DNA unit, which carries the gene of interest; (d) place the vector into a host cell, such as Escherichia coli or mammalian cells, and grow them in culture; (e) induce the production of the gene product of interest; and (f) extract and purify the gene product of interest (Consortium et al., 2008; Wurm, 2004).

The above described approach perhaps seems cumbersome, but it allows the production of molecules that are too complex, too expensive or just impossible to produce by chemical synthesis. Among this complex molecules are also biopharmaceuticals. The majority of biopharmaceuticals are therapeutic proteins, these can be further divided into groups: (i) blood factors; (ii) hormones; (iii) growth factors; (iv) monoclonal antibodies(Rader, 2008).

The idea that therapeutic proteins could be practically achievable by biotechnology methods matured in the beginning of the 1970s. But it needed a decade of research and development (R\&D) activities before the first products could be patented and prepared for the market. One of the first biotechnological products, (the early 1980s) was the recombinant human insulin (a hormone) form 
Genentech that was soon followed by the human growth hormone (from Genentech), erythropoietin (a hematopoietic growth factor) by Amgen, just to name the first few (Coan \& Ron, 2001). After this first wave of biopharmaceuticals in the 1980s, came the second wave with more complex products, such as monoclonal antibodies in the 1990s (Waldmann, 2003).

Now more than 30 years after the market launch of the first biopharmaceutical product, the biotechnology industry has been, most of the time, unprofitable in the aggregate. This can be credited to the circumstance that the number of emerging R\&D-phase companies dwarfs the number of profitable enterprises (Ernst \& Young, 2013). The R\&D-phase frequently exceeds 10 years and in this period no profits are generated. To bridge the time to the market introduction of the product, biotechnological companies implement strategies to create other sources of income. These strategies include providing services to universities and industry; acquiring R\&D contracts from governmental and other institutions. Also alliances with industrial partners, can have strategic importance (Glick, 2008). The motivations of a biotechnological company to establish an alliance with an industrial partner are two-fold; the objective is to accelerate the time to product launch and enhance the company's market value.

Typical alliances are made between biotechnological companies and pharmaceuticals companies (Nicholson et al., 2002). These alliances can lead to even closer cooperation and ultimately to mergers or acquisitions. The abovementioned company Genentech, merged with a pharmaceutical company Roche in 2009. This is an example when a big pharmaceutical company uses the know-how of biotechnological companies to augment its drug pipelines. More mergers and acquisitions (M\&A) followed the following years (Rossi et al., 2013).

Today, the biotechnological industry has a roughly global revenue of $55.09 \times 10^{9}$ EUR and an annual growth of $10 \%$ (Bloomberg, 2014). The traditional locations are the US and Europe - as Asia is quickly catching up.

\section{Investments in biotechnology sector: Best practices of developed regions}

To paint a picture about the investment trends in biotechnology, three regions will be compared in this section. The regions were picked based on their geographical location and maturity of the biotechnological industry. For the US we have selected the Boston area, as it is a traditional biotechnology location. For Europe, we have picked Switzerland. Switzerland has favorable conditions for the biotechnological industry, and for Asia we chose Singapore. Singapore has a leading position for research and contract research companies in Asia Pacific.

The three regions are compared based on four indicators: (1) number of students enrolled into science and engineering programs, (2) R\&D expenditure, (3) average number of citation per paper, published in Thomson Reuters-indexed journals from a 10-year plus 8-month period, and (4) number of publicized scientific articles for each given year. The first two indicators are measuring the inputs in to the innovation system. The first indicator, the number of students enrolled into science and engineering programs relative to 1000 inhabitants, is shown in Figure 1. This metric gives an estimate of the possible high skilled workforce for a high-tech business sector. The R\&D expenditure is presented as a percentage of the regions gross domestic product (GDP) and shown in Figure 1 in the right chart. Higher R\&D expenditure means that more ideas are tested and investigated in different laboratories and more knowledge is accumulated. More knowledge can lead to new products and even crate new markets. The third and fourth indicators are 
measuring the quality and quantity of the R\&D activities. The number of citations for a scientific paper is a metric that represents the quality of presented ideas in the published papers. In Figure 2, (right chart) the average number of citation per paper is shown. Each point is showing the moving average for 10 years. This gives a rough estimate on the overall level of quality of the published publications. The last indicator is aiming to grasp the size of the R\&D activities in the given region. Figure 2, (right chart) is showing how many scientific papers a published per 1000 inhabitants per year. A higher number suggests more R\&D activity.

In the following paragraphs, the three regions will be described in more detail. The emphasis is put on the scientific institutions, the business networks and funding environment.

Figure 1

Enrolled into science and engineering study programs and R\&D expenditure

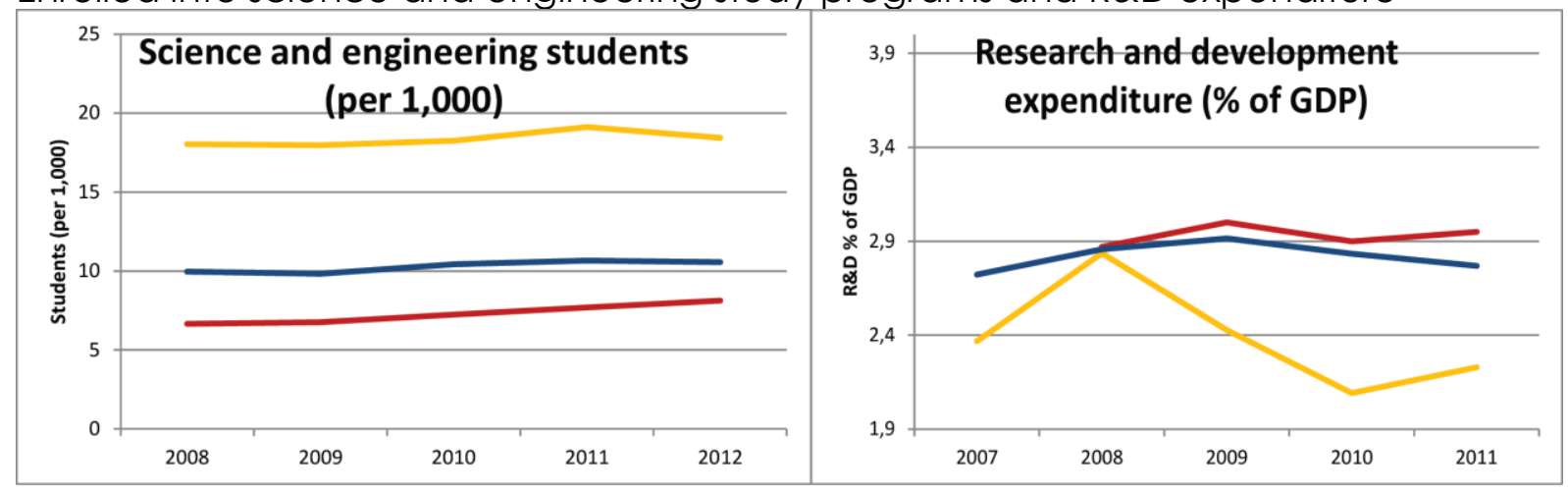

- Switzerland Singapore United States

Sources: UNSD, 2011; WorldBank, 2014b

\section{The Boston area}

Boston is hosting 33 institutions of higher education (NCES, 2014), among them are world known academic institutions and centers of biotechnology excellence. These institutions are located in the greater Boston area. Additionally, the greater Boston area also has a geographic concentration of business that supports and interconnects all aspects of the biotechnology industry including pharmaceuticals, medical devices diagnostics and bioinformatics. This network of organizations includes more than hundred different kinds of organizations, like biotechnology companies, universities, research clinics and other venture capital firms (Owen-Smith \& Powell, 2006). Best known academic institutions with basic research capabilities are for example: Harvard University, University of Massachusetts, Boston University, Massachusetts Institute of Technology (MIT) and Tufts University. These institutions also offer advanced degrees in biosciences. The highest founded clinics and hospitals are: Brigham \& Women's Hospital, Massachusetts General Hospital, Dana-Farber Cancer Institute, Beth Israel Hospital, and Children's Hospital. Multinational pharmaceutical firms only recently moved some R\&D activities to Boston.

A characteristic for the Boston area is a strong linkage between the academic research sector and the biotechnological community (Owen-Smith \& Powell, 2006). Many biotechnological companies have chosen put their central operations or administration in Boston, because they want to benefit from the proximity of many other biotechnological companies and the prominent academic and research institutions. Boston's intellectual infrastructure is mature with a high number of research employees, hospital and medical employees. Boston is well above the US 
national average. For example, the Boston area average for Science and Engineering students per 1000 citizens is about 28, the US national average is around 10, as shown in Figure 1 in the left chart.

Boston has a lot to offer from the financial and political site as well. The State of Massachusetts provides ways of reducing taxes for businesses and other offerings to support its biotechnological industry. An example is the Massachusetts Life Sciences Center (MLSC), this is an state-funded agency that manages the implementation of a 10-year, \$1-billion (894.4-million $€$ ) (MLSC, 2014). Along this specific local state funded incentives for biotechnology, there are more general funding opportunities for all disciplines of basic research issued from the Federal Government. The State of Massachusetts was granted a $\$ 8$ billion (7.2 billion $€$ ) from federal R\&D funds in one singe fiscal year 2009 (Yamaner, 2012). This adds to the fact that the R\&D expenditure of State Massachusetts is among the highest worldwide. R\&D expenditure amounted to $5.4 \%$ (in 2009) of the GDP (Wolfe, 2012) and is well above the US average, at $2.9 \%$ or Switzerland and Singapore as seen in Figure 1 (right chart). The Boston area's biotechnology sector is well positioned; it can continue to provide employment opportunities and attract business and investors.

Figure 2

Citations of scientific papers (average), and relative number of yearly publicized scientific articles

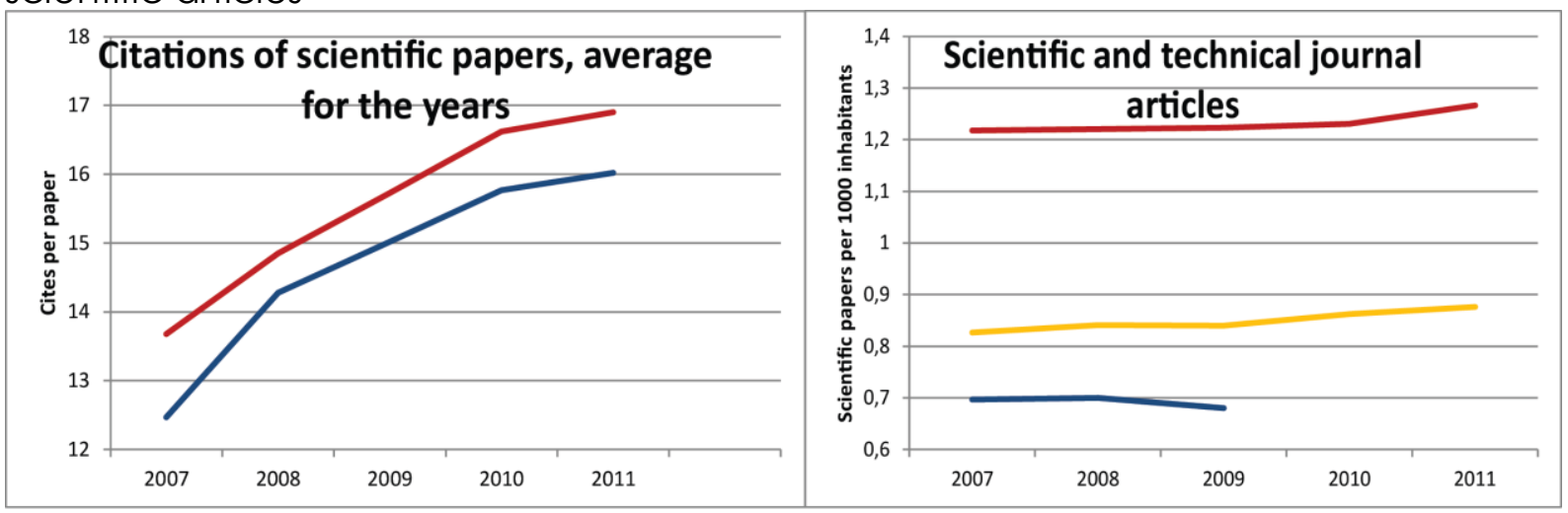

- Switzerland Singapore United States

Note: Number of citations is not available for Singapore

Sources: Schafer, 2011; WorldBank, 2014c

\section{Switzerland}

The most notable strengths that Switzerland can offer are: innovation, labor market efficiency and sophistication of its business sector (Schwab \& Sala-i-Martín, 2014). The scientific research institutions publish a relatively high number of research articles (Figure 2, right chart); furthermore the quality of the publications is the highest worldwide and is increasing. This is shown on the left chart in Figure 2. This makes Switzerland one of the most interesting regions in scientific research.

The Swiss Federal Institute of Technology Zurich (ETH) is among the highest ranked university in the World. Beside the ETH, the University of Zurich, with its University Hospital, has also a high ranking among European universities (ShanghaiRanking, 2014). All the above mentioned institutions are located in close geographical proximity. This is facilitating a rich cooperation between the institutions complementary research and advanced academic programs at the same time. Switzerland's biotechnological companies are showing a vast range of sizes, from Multinational Corporation to innovative start-ups. The mains clusters of 
biotechnological companies are located in Basel (BioValley), Zurich and Geneva (BioAlps) (JLL, 2012).

Biotechnological companies can find assistance for spin-offs in the highly concentrated biotechnological industry, universities and government (Zürcher, 2005). The headquarter of a couple of big pharmaceutical companies in Basel, and the strong financial sector in Zurich, also serves as leading powers for new innovation and development. Joint activities among academic institutions and the private sector create a favourable environment for start-up companies. Universities provide affordable laboratory space in the initial years, and later on, biotechnological business incubators provide opportunities for further growth (AWA, 2012).

Innovation and creativity is abundant in Switzerland, also in a European setting (Hollanders \& Es-Sadki, 2014). Biotechnology companies are strongly represented among the start-up companies in Switzerland, especially because they are benefiting from good access to private capital and public funding (EAER, 2014). In Switzerland, the Swiss National Science Foundation (SNSF) is the lead provider for funding of basic science activities on a federal level. It is funding a broad spectrum of disciplines with an annual fund size of 700-million CHF (650.2-million $€$ ). The size of available capital for biotechnological companies from 2010 to 2012 was $\$ 250$-million (232.2-million $€$ ) per annum, including equity financing and non-equity financing (loans, grants ...). With its dynamic combination of academic institutions, high concentration of biotechnological companies and well developed infrastructure, Switzerland's position as a global biotechnological innovator is excellent.

\section{Singapore}

Singapore is a new player in biotechnology and has entered this field in an effort to diversify its economy. Singapore is trying to make biotechnology the forth pillar of its economy. Singapore is already successful in electronics, chemicals, and precision engineering. The country has showed an impressive economic growth in the past decades (1960-2013), where the country had an averaging 7\% GDP growth per annum (WorldBank, 2014a). Such rapid growth could not be achieved without continuous industrial restructuring and technological upgrading. A further step in this direction was the announcement of the National Biomedical Science (BMS) Strategy in 2000. This strategy was a 5-year project including new institutes, academic research, and training in biotechnology as well as a tax incentive for both multinational pharmaceutical companies and home-grown biotechnological startups. The project had an initial fund of \$2-billion (1.27- billion $€$ ) (Van Epps, 2006). This was just the first of the three phases. Phase 1 lasted from 2000 to 2005; the second phase from 2006 to 2010 and the third one started in 2011 and ended in 2015. The fourth phase has already begun; the fifth phase was already announced. All this activities are coordinated by Singapore's Agency for Science, Technology and Research (A*STAR) and the Singapore Economic Development Board (SEDB) (Lim \& Gregory, 2004).

With its entire newly build infrastructure, Singapore serves as a common target for outsourcing of contract research and manufacturing. But also clinical research is transferred and performed by multi-national companies in Singapore for the Asia Pacific market. A high number of global pharmaceutical corporations coordinate their Asia Pacific operations from Singapore. Several of these global pharmaceutical companies have invested, beside administration and offices, also in R\&D on the island-country. This investments facilities knowledge spill-overs to local firms and helps Singapore transfer itself from a technology adapting location to a technology crating nation. As we see on the right chart in the Figure 2, the number of articles is 
increasing. This indicates more R\&D activities. Singapore's government is investing in high end research parks. The largest research park, Biopolis, is located in proximity of the National University of Singapore and the National University Hospital. During the first phase of BMS, Biopolis was established as a multi-building biotechnological complex, which was completed in 2003. More buildings were added in following phases of the BMS. To support the R\&D operation with local graduates, the Singaporean government redesigned the local education system in order to fulfill all research needs (Wong et al., 2009). The government provides support for the universities by the National Research Foundation (NRF) and the Education Ministry. Beside these institutions, Singapore has a plethora of boards and councils to encourage the development of the biotechnological industry. The functions and capabilities of this institutions range from assistance, starting with fund raising for basic R\&D and ending with setting up the production of a biotechnological product for Start-up Company. These efforts are accompanied by implemented strong intellectual property protection laws. The government of Singapore has a bigger influence on its biotechnological industry as in the US or Switzerland, but the industry is still developing.

\section{Current state of biotechnology sector in selected Eastern European countries}

Based on the relative quantity of published scientific articles shown in Figure 3, the biotechnological sector in the EE countries is very unevenly developed. The chart in Figure 3 is showing how many scientific papers are published per 1000 inhabitants per year; this is the same indicator as in Figure 2, right chart. A higher number suggests more R\&D activity. The best performing country (Slovenia) publishes six times more articles in scientific and technical journals than the worst preforming country, which is Romania. Such a huge difference is not at all present among the USA, Switzerland and Singapore as shown in the previous section (see Figure 2, right chart).

Figure 3 Number of published papers in scientific and technical journals per 1000 inhabitants

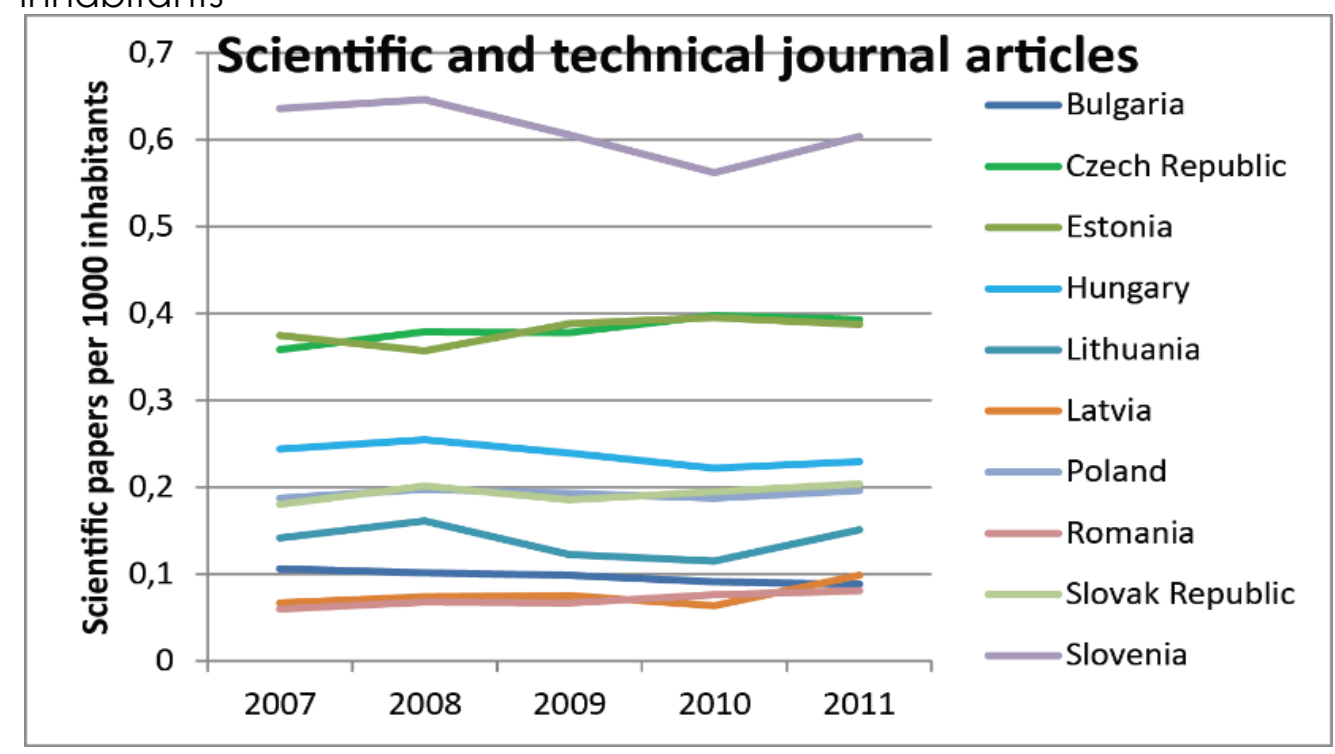

Source: WorldBank, 2014c 
The ten countries are clustered into three groups, as can be seen in Figure 3. The first group features only Slovenia, the second group includes Estonia and the Czech Republic, and the third group includes the rest of the EE countries, which are: Bulgaria, Hungary, Lithuania, Latvia, Romanian and the Slovak Republic.

The potential of good investments depends on many factors, where the common aim is to achieve a fast and sustainable growth. To reach this goal, a successful location analysis and selection have to be executed. This is achieved with analyzing the macroeconomic and business framework conditions. Factors of importance in the process of site selection can be: business sophistication, free trade and investment protection agreements, government efficiency, influence of innovation on the economy, labor cost, productivity, labor market flexibility, degree of workforce internationalization, common prices for goods, services and rents, general quality of living, general infrastructure and international air traffic connections. All the above mentioned economic factors together with indicator of scientific activity such as published scientific publications, can give a better answer for the current state of biotechnological in the EE countries.

In this section we will compare some of the above mentioned factors and indicators for Switzerland, Singapore and the United States with the EE countries. The goal is to find similarities and differences, with the purpose to locate gaps and find opportunities.

\section{Gross income}

Salary costs can have a high importance on the competitiveness of a site, and consequently in the selection process of the location of an investment. In this comparison, immense differences are observed between the countries. The observed differences are on the gross income level for comparable groups and income levels of the workforce.

Table 1

The gross income per year in USD

\begin{tabular}{lccc}
\hline & $\begin{array}{c}\text { Department } \\
\text { managers }\end{array}$ & $\begin{array}{c}\text { Skilled industrial } \\
\text { workers }\end{array}$ & $\begin{array}{c}\text { Female } \\
\text { factory } \\
\text { workers }\end{array}$ \\
\hline Bulgaria (Sofia) & 18100 & 9300 & 5100 \\
Czech Republic (Prague) & 24500 & 15400 & 9200 \\
\hline Hungary (Budapest) & 25600 & 10900 & 6500 \\
\hline Estonia (Tallinn) & 51000 & 17900 & 10600 \\
Singapore (Singapore) & 51693 & 20177 & 13203 \\
\hline Lithuania (Vilnius) & 23600 & 17700 & 8500 \\
\hline Latvia (Riga) & 23300 & 15300 & 9300 \\
\hline Poland (Warsaw) & 20900 & 13200 & 8400 \\
\hline Romania (Bucharest) & 13900 & 7400 & 5800 \\
Slovenia (Ljubljana) & 56600 & 17900 & 12400 \\
Slovak Republic (Bratislava) & 20300 & 16300 & 12600 \\
\hline Switzerland (Zurich) & 137200 & 79800 & 53200 \\
US (New York) & 118200 & 79100 & 41300 \\
\hline
\end{tabular}

Source: Aisslinger, 2012

Table 1 shows the gross income per year in USD. The wage levels are representative for cities and different groups and levels occupation. Gross income can vary 
significantly between regions and cities within a country. In Table 1 the highest income cities were picket for the given country, this are typically the capital cities, the chosen cities are in parenthesis. According to data in Table 1, Romania is most favorable, while Switzerland is the most expensive on the list. But foreign exchange risks like the Swiss Franc or Romanian Leu against the Euro, have to be taken into account. From this point of view, the EE countries that have adopted the Euro have a more farmable position.

Productivity \& Efficiency

It is incomplete to consider only the gross incomes to access the effective labor expanses. In additional to the gross income level, metrics such as workforce efficiency, average annual working hours, holidays and paid vacations, have to be considered as well. These factors are summarized in Table 2.

Table 1

Productivity \& Efficiency ranking with annual hours and paid vacations days

\begin{tabular}{lccc}
\hline & $\begin{array}{c}\text { Productivity \& } \\
\text { Efficiency }\end{array}$ & $\begin{array}{c}\text { Average Working } \\
\text { Hours per Year }\end{array}$ & $\begin{array}{c}\text { Holidays and } \\
\text { paid vacations } \\
\text { (days) }\end{array}$ \\
\hline Bulgaria & 57 & 1894 & 20 \\
\hline Czech Republic & 34 & 1830 & 20 \\
Hungary & 56 & 1976 & 20 \\
Estonia & 41 & 1889 & 20 \\
Singapore & 19 & 2409 & 7 \\
\hline Lithuania & 26 & 1789 & 20 \\
Latvia & 31 & 1806 & 20 \\
Poland & 22 & 1929 & 20 \\
Romania & 38 & 1837 & 20 \\
Slovenia & 45 & 1649 & 20 \\
Slovak Republic & 23 & 1785 & 20 \\
Switzerland & 6 & 1636 & 20 \\
USA & 5 & 1787 & 0 \\
\hline
\end{tabular}

Source: IMD, 2013 and OECD, 2013

The first column in Table 2 shows a ranking for "Productivity \& Efficiency" based on the IMD World Competitiveness Yearbook 2013 (IMD, 2013).The Annual Hours Worked per Employed Person is shown in the second column of Table 2 (OECD, 2013). In the last column of Table 2, the minimal number of holidays and paid vacations days are presented for each given country.

As Table 2 suggest, the United States together with Switzerland, have one of the most productive workforce in the world, thus helping mitigate the high salaries in the US and in Switzerland (Table 1). In the US the employers are not obligated to offer paid holidays and paid vacations, but otherwise in this category no noticeable differences are present. Singapore has the highest working hours in the table combined with a high productivity, but Singapore has not the highest productivity. Hungary and Poland have relative high number of working hours, compared to Slovenia, as the country has a low number of working hours. The productivity is low in all EE countries. 
Higher Education, Labor Market and Venture Capital

Lower labor costs in combination with the working hours and the proximity of the West European markets, can be seen as an advantage in comparison to other low cost locations.

Table 2

Competitiveness of higher education, labor market and venture capital availability

\begin{tabular}{lccc}
\hline Country & $\begin{array}{c}\text { Higher education } \\
\text { and training }\end{array}$ & $\begin{array}{c}\text { Labor market } \\
\text { efficiency }\end{array}$ & $\begin{array}{c}\text { Venture capital } \\
\text { availability }\end{array}$ \\
\hline Bulgaria & 69 & 61 & 65 \\
Czech Republic & 39 & 81 & 74 \\
Hungary & 44 & 85 & 122 \\
Estonia & 23 & 12 & 30 \\
Singapore & 2 & 1 & 6 \\
Lithuania & 27 & 69 & 84 \\
Latvia & 40 & 26 & 58 \\
Poland & 37 & 80 & 104 \\
Romania & 59 & 110 & 92 \\
Slovenia & 25 & 106 & 127 \\
Slovak Republic & 58 & 76 & 64 \\
Switzerland & 4 & 2 & 22 \\
USA & 7 & 4 & 3 \\
\hline
\end{tabular}

Source: WEF, 2014

The WEF Global Competitiveness Report (WEF, 2014) compares 148 countries in different categories, called "pillars" and ranking them. Higher the placements in the given pillar better the competitiveness of the country. In Table 3 three pillars on higher education, labor market and venture capital for the selected countries are shown.

Higher educated and trained work force is essential for developing a biotechnological company, and high-tech companies at general. As shown in Table 3 , the highest rank in higher education and training occupies Singapore. Singapore combines a quality higher educational training with a relatively high number of students, Figure 1; left chart. Some of the EE countries are ranked quite well, like Estonia and Slovenia. As biotechnological companies tend to be smaller and highly specialized ventures, an efficient labor market can be an advantage in order to recruit the best people. On labor market efficiency, the EE countries rank low in the World Economic Forum (WEF) of the Global Competitiveness Report ranking, shown in Table 3. Expect Estonia, which is ranked above all EE countries in the ranking for labor market efficiency. Typical biotechnological projects tend to be cost intense, as a consequence financial markets tent to be an important factor in financing the ventures. The venture capital availability ranked by WEF in Table 3, attributes the highest ranking position among the EE countries to Estonia. Not surprisingly USA and Singapore are leading the list.

\section{Intellectual Property and Suppliers}

The biotechnological industry is R\&D-driven by its nature. Purchase or development of intellectual property (IP) as well as the production of complex products is of central importance. The central questions are where the IP has been or could be developed. The following question is profitmaking. This is in more detail where, how 
and at what stage and price it should be moved from the place of development to the place of exploitation.

From the WEF Global Competitiveness Report(Schwab \& Sala-i-Martín, 2014), where countries are compared and ranked based on their competitiveness, the categories on intellectual property and suppliers are shown in Table 4. The Table 4 shows four categories: property rights, intellectual property protection, local supplier quality and quality of overall infrastructure.

Table 4 shows how strongly the intellectual property is protected in each country. In this ranking Singapore has the highest position. The US has a surprisingly low ranking position, close to Estonia and Romania occupies the lowest position. The picture is similar for the overall Property Rights ranking in Table 4, where Estonia is just one place behind the USA.

Table 3

The competitiveness of the intellectual property protection and suppliers

\begin{tabular}{|c|c|c|c|c|}
\hline & $\begin{array}{l}\text { Property } \\
\text { rights }\end{array}$ & $\begin{array}{c}\text { Intellectual } \\
\text { property } \\
\text { protection }\end{array}$ & $\begin{array}{l}\text { Local } \\
\text { supplier } \\
\text { quality }\end{array}$ & $\begin{array}{l}\text { Quality of overall } \\
\text { infrastructure }\end{array}$ \\
\hline Bulgaria & 111 & 104 & 72 & 102 \\
\hline Czech Republic & 88 & 61 & 21 & 37 \\
\hline Hungary & 103 & 58 & 70 & 49 \\
\hline Estonia & 34 & 31 & 25 & 33 \\
\hline Singapore & 2 & 2 & 28 & 5 \\
\hline Lithuania & 71 & 66 & 34 & 44 \\
\hline Latvia & 62 & 51 & 53 & 50 \\
\hline Poland & 66 & 72 & 51 & 84 \\
\hline Romania & 82 & 110 & 104 & 106 \\
\hline Slovenia & 69 & 42 & 33 & 31 \\
\hline Slovak Republic & 83 & 65 & 41 & 81 \\
\hline Switzerland & 3 & 5 & 1 & 1 \\
\hline USA & 33 & 25 & 10 & 19 \\
\hline
\end{tabular}

Source: Schwab \& Sala-i-Martín, 2014

The attractiveness of a location for an investment as a R\&D-site or production is characterized with a good access for supplies. Two rankings try to describe this in Table 4 named "Local supplier quality" and "Quality of overall infrastructure". Switzerland is ranked best in both categories. The top scores among the EE countries belong to Slovenia, Estonia and the Czech Republic. In the above cases, the lack of international flight connections is dragging down the ranking of the EE countries.

\section{Development of biotechnology sector in selected Eastern} European countries: Causes of current state and future

\section{directions}

Causes of underdevelopment of biotechnological sector

The reasons for a low level of investments in biotechnology among the EE countries are divers. They range from shared history to difficulties to access financing in recent times. In this section we will first discus the historical heritage and then proceed to more recent challenges. 
Cause 1: Former centrally planned economies. The former centrally planned economies of the EE countries were of a closed nature. In consequence their scientific community did not want or could not take part in the international scientific discussion and R\&D community exchange (Radosevic \& Auriol, 1999). Scientific results were not always published in English journals. This hindered the international communication of scientific results. Moreover, in the epoch of centrally planned economy, the science funding focused around some scientific fields, like physics and chemistry, biosciences were in this circumstances underrepresented (Kozlowski et al., 1999). The reason to neglect research in biosciences originated from at least two reasons; (1) most government encouragement was focused on research areas that could serve the military/industrial complex and (2) basic and theory oriented topics were favored in order to minimize the dependents of expensive equipment. Biosciences cannot fulfill these two criteria, because it requires costly research and experimental work (Senker et al., 2012).

Cause 2: Political instability during the period of transition. The former centrally planned economies appeared in a period of transition, starting 1989. The transition involved the transformation of a centrally planned economy to an open market economy. As a consequence, these transitions brought some political instability, which had an impact on foreign direct investment(Brada et al., 2006). In some EE countries a consequence of this transition period resulted in sporadically formed biotechnology-related capacities as well as infrastructure and resource deteriorated. This deterioration was initiated because of the drastically reduced demand in the Eastern Bock. This collapsed market in the Eastern Bock was combined, with the inability to enter new markets(Senker et al., 2012).

Cause 3: Higher education and training is lagging behind. As the above historical overview summarizes, biotechnological is not historically anchored in this region. But as biotechnological is, in essence, a new science based industry; its beginnings should be found at institutions of higher education. Such as academic start-ups or spin-off companies from universities. Highly educated and specialized staff is needed for biotechnological companies. The low number of biotechnological companies can be explained on the basis of international ranking of higher education and training. Higher education and training is lagging behind in the $\mathrm{EE}$, the exceptions being Estonia, Slovenia and Lithuania as shown in Table 3. All these three countries are also ranking 16 places behind the USA, which is the bottom among the developed regions in this respect. This gap can be critical for high tech industries, like biotechnological.

Cause 4: Poor efficiently of the labor market. Perhaps university graduates are not the best choice for certain projects, as they are too inexperienced. At this point, an efficiently working labor market is crucial in finding and recruiting the best talents possible. In Table 3, the ranking positions for the EE countries and the three developed markets are represented. Except Estonia and Latvia, all EE countries have low rankings. Singapore and Switzerland are here leading the list. Additionally to human capital, venture capital availability can be crucial to set up a risky high tech venture. Each country's venture capital availability is presented in Table 3. The overall picture is similar to higher education and training ranking as well as labor market efficiency. Singapore, Switzerland and the US are at the top of the list and the $\mathrm{EE}$ countries are at the bottom. Estonia has the leading position among the $\mathrm{EE}$ countries.

Cause 5: Insufficient intellectual property protection. High tech ventures like biotechnological are sensitive to intellectual property protection. Rankings in Table 4 
are suggesting a gap between the EE countries and the developed regions. Estonia yet again is being the exception, whilst ranking close to the US.

The overall picture suggests that biotechnological is not historically present in the EE countries and that the current conditions are not in any way encouraging. The described business environment combined with an inefficient government bureaucracy is hindering start-ups (Kochanova, 2012; Mungiu-pippidi, 2014). In addition, difficult access to financing is hindering the innovators on their way to success.

Recommended strategy for the development of biotechnology sector

The entire group of the EE countries ranked low in Table 4 (Property rights and Intellectual property protection). The score is also low on "Venture capital availability" in Table 3 . This all speaks against establishing a capital intense and intellectual property based business. On the other hand, data from Table 2, about wages, together with the scores in "Higher education and training" makes the region attractive again. The wages are low in comparison to Western Europe; this fact in turn can favor a production site with labor intense tasks. The relatively high score in some EE countries regarding "Higher education and training" suggest that highly educated graduates are available.

Beside the personal, raw materials have to be obtained and transported. For these tasks the following two metrics can be used: (1) the Local supplier quality and the (2) Quality of overall infrastructure from Table 4. The relatively low scores on "Quality of overall infrastructure" are largely tied with weaker international flight connections. But because of the proximity of the big West European airport hubs, the accessibility is still adequate. Raw materials can be obtained locally, as the scores under "Local supplier quality" suggest, this further reduces the costs of production. The geographical proximity of the major European markets for biotechnological products makes the EE countries attractive.

Recommendation 1: Transfer of production and research capabilities. All these above mentioned advantages show in the direction for a competitive cost of production. The gained advantage is compared with expensive and developed biotechnological locations like Switzerland. Production transfers to an EE country or even the transfer of a research to a Contract Research Organizations in the EE countries could give a competitive cost advantage. The transfer of production or part of the research process could give the local economy a know-how spillover. Knowledge could be transferred from the foreign companies to the local ones. This spillover effects could accelerate further investments in the region, and benefit both the EE countries with new jobs and the investor with higher profits.

Recommendation 2: Creating formal academic alliances. The aim by seeking formal academic connections is transfer of world class basic science. Investment in basic research could transform the EE countries from a technology adapting, to a technology creating region. Formal academic cooperation would foster a permanent communication between institutions on all levels. The aim would be to create a strong presence of the world class universities, such as Harvard, Cambridge and Stanford in the EE countries. And vice versa, the universities from the EE countries should establish a presence in research parks and technology centers (like Silicon Valley) around the world to transfer people and knowledge.

Recommendation 3: Good governance. Beside the above mentioned the EE countries should future exploit after adopting democracy, how could the EE countries adopt governance from the West and the EU. The aim should be to 
reducing the inefficient government bureaucracy. The resulting government bureaucracy would help start-ups and small high-tech business to grow rapidly.

Recommendation 4: Strengthen intellectual property protection. As the EE countries are showing some weaknesses in the intellectual property protection department, this should be upgraded, as this is crucial for high tech industries like biotechnological.

Recommendation 5: Include the civil society. But not forget about the civil society - the consumers and non-governmental organization. New technologies need the support from the society to get accepted and spared. Only when the new technology is perceived by the public in a positive light, will the community easily cooperate on large projects.

All the data from the previous sections shows different stage of development of the EE countries. Because of this, the solutions have to be unique for every region, with the aim to stenting the strengths and eradicate weaknesses.

\section{Conclusion}

Biotechnology bears the potential for a long-lasting community development, with the opportunity of job creation. For a region with a disproportional high youth unemployment (Kolev \& Saget, 2005). Exploring a high technology sector could give the possibility of highly paid occupations and reduce unemployment. But the sector bears high risks, since the R\&D-phase for a product can frequently exceed 10 years and no profits are generated during this period (Adelman \& Holman, 2009). This creates subsequent uncertainty of success in a rapidly changing market environment, where the products can rapidly get obsolete.

\section{Summary of the research}

The EE countries cannot rely solely on tier low-wage advantage over West European production locations. Over time the wage advantage can lessen and these advantages can diminish. A way to make the EE countries more competitive would be invest in productivity \& efficiency of the production. This kind of investments could be leveraged by infrastructure investments and know-how spillovers of foreign multinational companies. After the production and R\&D infrastructures are build, the EE countries should focus on their own entrepreneurs (Farrell, 2005).

To be able for fully utilize their production and R\&D infrastructure. All parties from industry, government to academia must cooperate to achieve the best possible result (Debackere \& Veugelers, 2005). Such cooperation has to be coordinated. The coordination must be led by an organization with a high reputation. In certain cases this roll can be fulfilled by the government, in a good governance way. New concepts or principles with market potential have to be recognized and protected; for this task intellectual property protection rules are needed.

The advantages, which are speaking for the region, are following: the proximity to Western Europe, relatively long working hours per year, relatively highly educated work force and its low labor costs. The relatively weak intellectual property protection can serve as an advantage in generic and biosimilar production circumstances (Walsh, 2014).

The regulators of the EE countries have to find the right balance of regulation to create an environment of cooperation between research institutions, industry and the government itself. 
Practical implications

Biotechnological industry promises high returns for those, who participate in it (Grullon et al., 2012). To obtain such high returns, a physical infrastructure must be present. The EE courtiers have to transfer from an adopting technology approach, to a creating technology approach, or even focus to lead in certain technological areas. The prerequisite for creating and lead in technology is R\&D. A high-end R\&D infrastructure has to be built to attract and leverage the best possible talent.

The EE countries have to cooperate with the international technology markets, dominated by North American and Western European firms. The entrepreneurs from the EE countries have to find their niches and try to obtain the leading position with innovation (Kim \& Mauborgne, 2004). The EE countries should find a way to enhance and foster an entrepreneurial spirit on their universities, business incubator facilities, academic spin-off initiatives and other research institutions (Meyer, 2003). The government could give support and monitor the process. Patenting and licensing of technologies as well as join R\&D projects between private firms and public research institutions could serve as indicators to follow the success.

\section{Limitations and future research}

This paper provides just a snap shot of the current situation. Biotechnology is evolving rapidly, data can render rapidly obsolete. The EE courtiers were treated in this paper as one entity, but in many aspects this is not true. There a huge differences on many levels between the countries.

Regions with a well-developed biotechnology business sector are evolving. More and different regions a becoming successful in biotechnology and the reference list from the beginning of this paper can become inadequate.

Despite the limitation of this paper to put a heterogeneous group of the EE countries together, common challenges could be found. A common challenge does not mean that the same solution fits all needs. To give an efficient recommendation every country or region with in the country should be treated separately.

The future research should explore the way of international academic cooperation. The universities form the EE countries should seek a strong linkage to foreign academic institutions and domestic industry. Explore routes for better governance and ways how to strengthen intellectual property protection. In this journey of technological transition, the support of the civil society is needed. Future research could explore ways to get the support of the civil society.

At last, the stories of the three successful biotechnological regions, from the beginning, are very different. There is no universal recipe to success, so every community has to find its own way to sustained prosperity - biotechnological could be one answer.

\section{References}

1. Adelman, D. \& Holman, C., (2009). "Misplaced Fears in the Legislative Battle Over Affordable Biotech Drugs". Idea, Vol.50 No.4, pp.565-591.

2. AWA, (2012). "Lifescience Zurich Booklet", Zurich.

3. Bloomberg, (2014). "Bloomberg". visual data.

4. Boschma, R., Heimeriks, G. \& Balland, P.-A., (2014). "Scientific knowledge dynamics and relatedness in biotech cities". Research Policy, Vol.43 No.1, pp.107114. 
5. Brada, J.C., Kutan, A.M. \& Yigit, T.M., (2006). "The effects of transition and political instability on foreign direct investment inflows.". The Economics of Transition, Vol. 14 No.4, pp.649-680.

6. Coan, T.D. \& Ron, E., (2001). "Generic Biologics: The Next Frontier", London.

7. Consortium, S.G. et al., (2008). "Protein production and purification". , Vol.5 No.2.

8. Debackere, K. \& Veugelers, R., (2005). "The role of academic technology transfer organizations in improving industry science links". Research Policy, Vol.34 No.3, pp.321-342.

9. EAER, (2014). "Swiss Biotech Report 2014",

10. Van Epps, H.L., (2006). "Singapore's multibillion dollar gamble.". The Journal of experimental medicine, Vol.203 No.5, pp.1139-42.

11. Ereky, K., (1919). "Biotechnologie der Fleisch-, Fett-, und Milcherzeugung im landwirtschaftlichen Grossbetriebe: für naturwissenschaftlich gebildete Landwirte verfasst", Berlin: P. Parey.

12. Ernst \& Young, (2013). "Beyond borders: global biotechnology report 2013". Beyond borders, No.27.

13. Essendorfer, S., Diaz-Rainey, I. \& Falta, M., (2015). "Creative destruction in Wall Street's technological arms race: Evidence from patent dataNo Title". Technological Forecasting and Social Change.

14. Fári, M.G. \& Kralovánszky, U.P., (2006). "The founding father of biotechnology: Károly (Karl) Ereky". International Journal of Horticultural Science, Vol.12 No.1, pp.9-12.

15. Farrell, D., (2005). "Offshoring: Value creation through economic change". Journal of Management Studies, Vol.42 No.3, pp.675-683.

16. Gerstein, M.B. et al., (2007). "What is a gene, post-ENCODE? History and updated definition.". Genome research, Vol.17 No.6, pp.669-81.

17. Glick, J.L., (2008). "Biotechnology business models work: Evidence from the pharmaceutical marketplace". Journal of Commercial Biotechnology, Vol.14 No.2, pp.106-117.

18. Gregersen, N. et al., (2006). "Protein misfolding and human disease.". Annual review of genomics and human genetics, Vol.7, pp.103-24.

19. Grullon, G., Lyandres, E. \& Zhdanov, A., (2012). "Real Options, Volatility, and Stock Returns". Journal of Finance, Vol.67 No.4, pp.1499-1537.

20. Hollanders, H. \& Es-Sadki, N., (2014). "Innovation Union Scoreboard 2014", Maastricht.

21. Hulse, J.H., (2004). "Biotechnologies: past history, present state and future prospects". Trends in Food Science \& Technology, Vol.15 No.1, pp.3-18.

22. IMD, (2013). "International Institute for Management Development". world competitiveness online.

23. JLL, (2012). "NoLife Sciences Outlook Switzerland . 2012", Zurich.

24. Junkunc, M.T., (2007). "Managing radical innovation: The importance of specialized knowledge in the biotech revolution". Journal of Business Venturing, Vol.22 No.3, pp.388-411.

25. Kim, W.C. \& Mauborgne, R., (2004). "Blue ocean strategy". Harvard Business Review, Vol.82 No.10, pp.76-84.

26. Kishore, G.M. \& Shewmaker, C., (1999). "Biotechnology: Enhancing human nutrition in developing and developed worlds". Proceedings of the National Academy of Sciences, Vol.96 No.11, pp.5968-5972.

27. Kochanova, A., (2012). "The Impact of Bribery on Firm Performance: Evidence from Central and Eastern European Countries", The Center for Economic Research and Graduate Education - Economic Institute, Prague. 
28. Kogan, L., Papanikolaou, D. \& Stoffman, N., (2015). "Winners and Losers: Creative Destruction and the Stock Market",

29. Kolev, A. \& Saget, C., (2005). "Understanding youth labour market disadvantage: Evidence from south-east Europe". International Labour Review, Vol.144 No.2, pp.161-187.

30. Kozlowski, J., Radosevic, S. \& Ircha, D., (1999). "History matters: The inherited disciplinary structure of the post-communist science in countries of central and eastern Europe and its restructuring". Scientometrics, Vol.45 No.1, pp.137-166.

31. Lim, L.P.L. \& Gregory, M.J., (2004). "Singapore's biomedical science sector development strategy: Is it sustainable?". Journal of Commercial Biotechnology, Vol. 10 No.4, pp.352-362.

32. Meyer, M., (2003). "Academic entrepreneurs or entrepreneurial academics? research-based ventures and public support mechanisms".

33. MLSC, (2014). "Massachusetts Life Sciences Center".

34. Mungiu-pippidi, A., (2014). "The Transformative Power of Europe Revisited". Journal of Democracy, Vol.25 No.1, pp.20-32.

35. NCES, (2014). "National Center for Education Statistics".

36. Nicholson, S., Danzon, P. \& McCullough, J., (2002). "Biotech-Pharmaceutical Alliances as a Signal of Asset and Firm Quality", Cambridge, MA.

37. OECD, (2014). "Defining biotechnology".

38. OECD, (2013). "Employment and Labour Markets: Key Tables from OECD", OECD Productivity Statistics.

39. Owen-Smith, J. \& Powell, W.W., (2006). "Accounting for Emergence and Novelty in Boston and Bay Area Biotechnology". In P. Braunerhjelm \& M. P. Feldman, eds. Cluster Genesis: Technology-Based Industrial Development. Oxford Scholarship, pp. 1-39.

40. Pearson, H., (2006). "Genetics: what is a gene?". Nature, Vol.441 No.7092, pp.398401.

41. Rader, R.A., (2008). "(Re)defining biopharmaceutical.". Nature biotechnology, Vol.26 No.7, pp.743-51.

42. Radosevic, S. \& Auriol, L., (1999). "Patterns of restructuring in research, development and innovation activities in central and eastern European countries: an analysis based on S\&T indicators". Research Policy, Vol.28 No.4, pp.351-376.

43. Rossi, M., Tarba, S.Y. \& Raviv, A., (2013). "Mergers and acquisitions in the hightech industry: a literature review". International Journal of Organizational Analysis, Vol.21 No.1, pp.66-82.

44. Schafer, S., (2011). "Top 20 Countries in ALL FIELDS". Essential Science Indicators.

45. Schwab, K. \& Sala-i-Martín, X., (2014). "The Global Competitiveness Report",

46. Senker, J., Enzing, C. \& Reiss, T., (2012). "Biotechnology in Central and Eastern Europe: An overview of performance and policy system". In Exploring Central and Eastern Europe's Biotechnology Landscape. pp. 13-35.

47. ShanghaiRanking, (2014). "Academic Ranking of World Universities 2013".

48. UNSD, (2011). "Expert Group discusses future work on classifications", New York.

49. Waldmann, T. a, (2003). "Immunotherapy: past, present and future.". Nature medicine, Vol.9 No.3, pp.269-77.

50. Walsh, G., (2014). "Biopharmaceutical benchmarks 2014". Nature biotechnology, Vol.32 No.7, pp.992-1000.

51. WEF, (2014). "Labor market efficiency". In The Global Competitiveness Report 2013- 2014. World Economic Forum, p. 10. 
52. Wolfe, R.M., (2012). "Business R \& D Performed in the United States Cost \$291 Billion in 2008 and $\$ 282$ Billion in 2009",

53. Wong, P.-K., Ho, Y.-P. \& Singh, A., (2009). "Industrial Cluster Development and Innovation in Singapore". In A. Kuchiki \& M. Tsuji, eds. From Agglomeration to Innovation. IDE-JETRO, pp. 50-116.

54. WorldBank, (2014) (a). "GDP growth (annual \%)". World Development Indicators.

55. WorldBank, (2014)(b). "Research and development expenditure (\% of GDP)". World Development Indicators.

56. WorldBank, (2014)(c). "Scientific and technical journal articles". World Development Indicators.

57. Wurm, F.M., (2004). "Production of recombinant protein therapeutics in cultivated mammalian cells.". Nature biotechnology, Vol.22 No.11, pp.1393-8.

58. Yamaner, M., (2012). "Federal Funds for Research and Development: Fiscal Year 2009-11",

59. Zürcher, J., (2005). "Swiss Biotech Report 2005", Winterthur.

\section{About the author}

Patrik Vida is currently a PhD student at the Faculty of Commercial and Business Sciences in Celje, Slovenia. His current research interests include innovating and innovation capacity of businesses in the area of biotechnology, investment in biotechnology in South-East Europe. He earned his diploma degree at the University of Tübingen, Faculty of Science in the field of Biochemistry. Author can be contacted at: patrik.vida@yahoo.de 